\title{
Endothelial progenitor cells in diabetic retinopathy
}

\author{
Noemi Lois*, Rachel V. McCarter, Christina O'Neill, Reinhold J. Medina and Alan W. Stitt \\ Centre for Experimental Medicine, School of Medicine, Dentistry and Biomedical Science, Queen's University Belfast, Royal Victoria Hospital, Belfast, UK
}

\section{Edited by:}

Ashay Dilip Bhatwadekar, Indiana

University, USA

\section{Reviewed by:}

Kay Waud, Jones Institute for Reproductive Medicine, USA

Undurti Narasimha Das, UND Life

Sciences, USA

\section{*Correspondence}

Noemi Lois, Centre for Experimental Medicine, School of Medicine,

Dentistry and Biomedical Science,

Queen's University Belfast, Royal

Victoria Hospital, Belfast BT12 6BA,

Northern Ireland, UK

e-mail:n.lois@qub.ac.uk

\begin{abstract}
Diabetic retinopathy (DR) is a leading cause of visual impairment worldwide. Patients with DR may irreversibly lose sight as a result of the development of diabetic macular edema (DME) and/or proliferative diabetic retinopathy (PDR); retinal blood vessel dysfunction and degeneration plays an essential role in their pathogenesis. Although new treatments have been recently introduced for $\mathrm{DME}$, including intravitreal vascular endothelial growth factor inhibitors (anti-VEGFs) and steroids, a high proportion of patients $(\sim 40-50 \%)$ do not respond to these therapies. Furthermore, for people with PDR, laser photocoagulation remains a mainstay therapy despite this being an inherently destructive procedure. Endothelial progenitor cells (EPCs) are a low-frequency population of circulating cells known to be recruited to sites of vessel damage and tissue ischemia where they promote vascular healing and re-perfusion. A growing body of evidence suggests that the number and function of EPCs are altered in patients with varying degrees of diabetes duration, metabolic control, and in the presence or absence of DR. Although there are no clear-cut outcomes from these clinical studies, there is mounting evidence that some EPC sub-types may be involved in the pathogenesis of DR and may also serve as biomarkers for disease progression and stratification. Moreover, some EPC sub-types have considerable potential as therapeutic modalities for DME and PDR in the context of cell therapy. This study presents basic clinical concepts of DR and combines this with a general insight on EPCs and their relation to future directions in understanding and treating this important diabetic complication.
\end{abstract}

Keywords: diabetic retinopathy, diabetic macular edema, endothelial progenitor cells, ischemia, proliferative diabetic retinopathy, retina, hematopoietic stem cells, vessels

\section{DIABETIC RETINOPATHY}

\section{A WORLDWIDE DISEASE WITH INCREASING PREVALENCE}

Diabetic retinopathy (DR) is the most common microvascular complication of diabetes mellitus (DM) and a leading cause of visual loss among individuals of working age $(1,2)$. Due to the ever-increasing numbers of people with DM, principally the type 2 form of disease, it is expected that the burden of DR will continue to rise. Indeed, it has been estimated that the worldwide prevalence of DR will increase from 126.6 million in 2010 to 191 million by 2030 (3).

Diabetic retinopathy occurs more frequently in people with poor glycemic control and with longer duration of diabetes (4). Other major risk factors include hypertension (5), renal disease (6, 7), and dyslipoproteinemia $(8,9)$. The Diabetes Control and Complications Trial (DCCT) (10) and the United Kingdom Prospective Diabetes Study (UK-PDS) (5) demonstrated the importance of keeping a tight glucose control on delaying the onset and slowing the progression of DR in people with type 1 and type 2 DM, respectively. The UK-PDS demonstrated that maintaining adequate levels of blood pressure ( 140/80) reduced the risk of $\mathrm{DR}$ in people with $\mathrm{DM}$ type 2 (5). Although $\mathrm{HbA}_{1 \mathrm{c}}$, an index of prolonged hyperglycemia, remains the strongest risk factor for predicting progression of DR, this parameter accounted for only $11 \%$ of the risk of retinopathy in the DCCT (11). Furthermore, $\mathrm{HbA}_{1 \mathrm{c}}$, blood pressure, and total serum cholesterol, together, accounted for only $9-10 \%$ of the risk of DR in the Wisconsin epidemiologic study of diabetic retinopathy (WESDR) (12). The situation continues to become ever-more complex, and recent evidence suggests that sleep apnea $(13,14)$ and changes in serum prolactin (15), adiponectin (16), and homocysteine (17) may affect the progression of DR.

\section{CLINICAL FEATURES AND CLASSIFICATION}

The earliest retinal abnormalities detected in people with DM appear to be functional in that they occur in a fundus, which appears normal. Functional changes in the diabetic retina include abnormal electroretinographic responses $(18,19)$, changes in blood flow, and loss of autoregulatory mechanisms that adjust retinal capillary perfusion (20). As DR progresses, microaneurysms, retinal hemorrhages, hard exudates (lipid leakage), and "cotton wool spots" (localized disruption of axoplasmic flow) may develop, which are readily observed upon fundus examination. In late stages of DR, venous beading (irregularity in the caliber of the retinal veins with saccular dilations and thinning of the vein wall), intraretinal microvascular abnormalities (IRMA), and intra-retinal and/or pre-retinal neovascularization will ensue.

Based on the absence or presence of neovascularization, patients with DR are classified as having non-proliferative diabetic retinopathy (NPDR) or proliferative diabetic retinopathy (PDR), respectively (Figure 1). The fundus of patients with severe NPDR are typically characterized by the presence of retinal hemorrhage and/or microaneurysms in four retinal quadrants, venous 

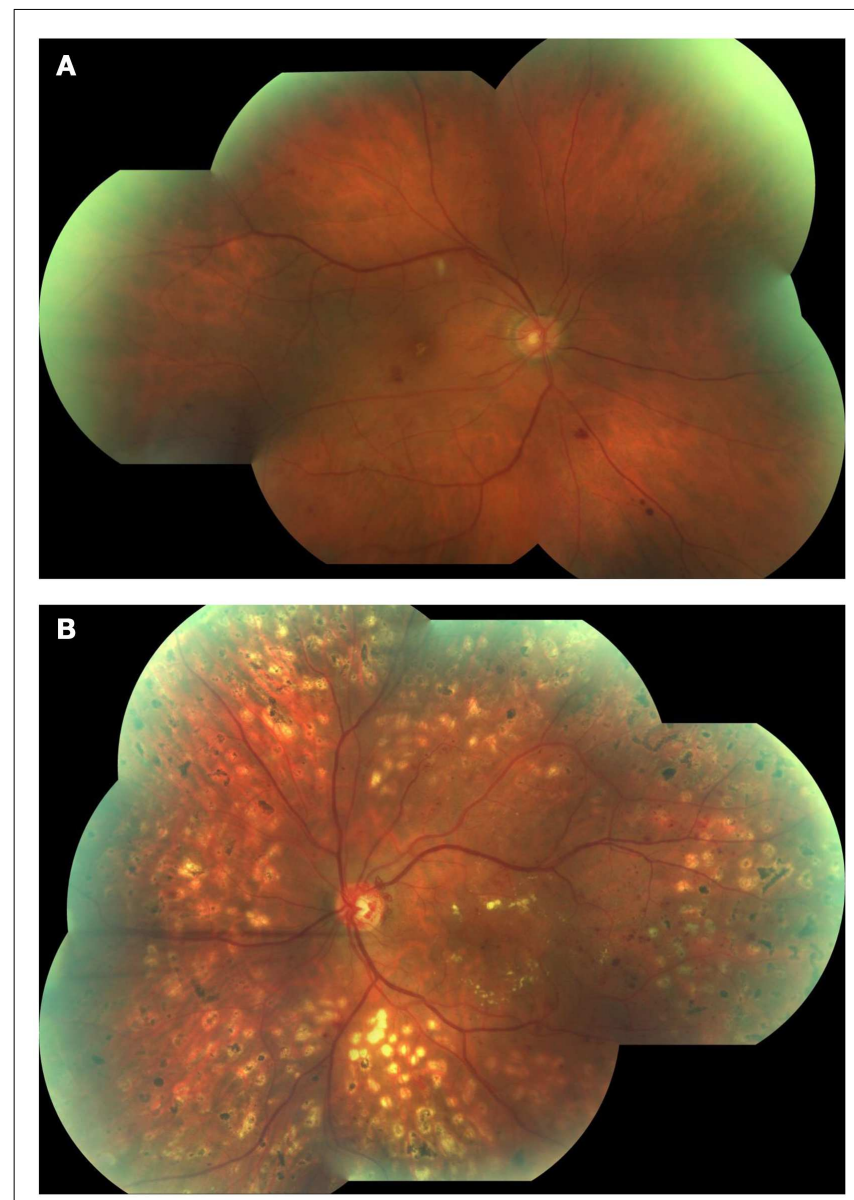

FIGURE 1 | Fundus photographs obtained from patients with non-proliferative diabetic retinopathy (NPDR) (A) and proliferative diabetic retinopathy (PDR) (B). Note few hemorrhages and a cotton wool spot at the superior aspect of the macula in (A), and marked neovessels in the disc and macular exudation in (B).

beading in two retinal quadrants, or IRMA in one retinal quadrant (known as the "4-2-1 rule"). These patients are at higher risk of progression to PDR. At NPDR or PDR stages, there may be overt breakdown of the inner and/or outer blood retinal barrier (BRBs) with characteristic diabetic macular edema (DME) (Figure 2). The accumulation of fluid at the center of the retina occurring in DME constitutes the leading cause of visual loss among people with DR.

\section{VASCULAR ABNORMALITIES}

The pathological sequence of retinal vessel abnormalities in DR includes early and progressive thickening of the basement membrane and dysfunction and loss of endothelial cells, pericytes, and vascular smooth muscle [reviewed by Curtis et al. (21)]. Progressive capillary non-perfusion and ensuing ischemia in the diabetic retina may induce hypoxia-related up-regulation of cytokines and growth factors, such as vascular endothelial growth factor (VEGF) $(22,23)$, and this drives vasopermeability (DME) and/or abnormal neovascularization (21).
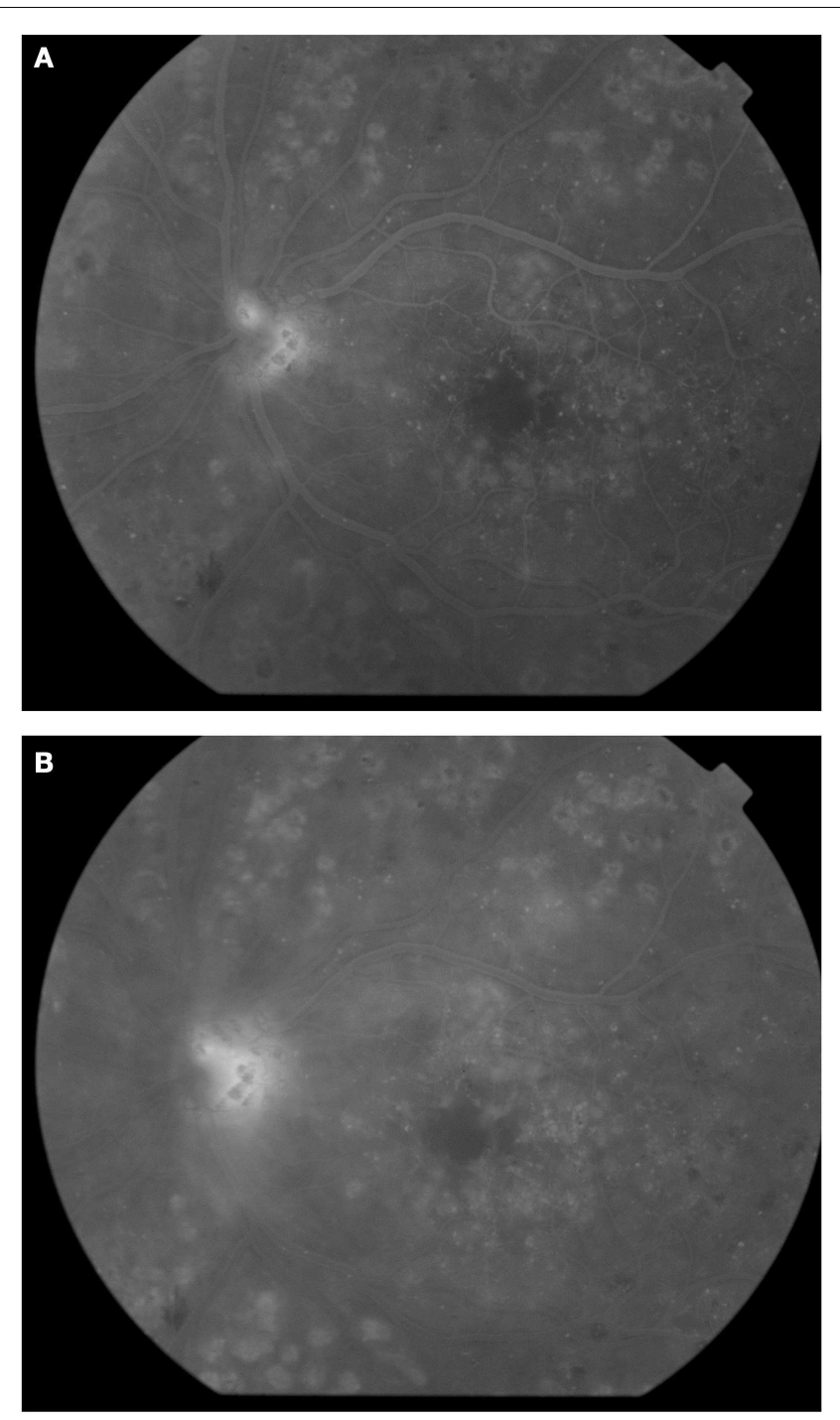

FIGURE 2 | Fluorescein angiography obtained from the left eye of a patient with diabetic macular edema and PDR. Note drop out of perifoveal capillaries (A) with late leakage (B) and leakage from neovessels at the disc $(\mathbf{A}, \mathbf{B})$.

The diabetic milieu is highly damaging to the retinal capillary endothelium and this results in a significantly greater turnover of these cells when compared to non-diabetic equivalents (24). Exhaustion of endothelial cell replicative capacity and cells reaching their so-called Hayflick limit (25) means that the retinal vasculature in diabetic patients has impaired regenerative capacity. This underlines the progressive degenerative nature of DR in most patients.

\section{RETINAL ISCHEMIA AND DIABETIC RETINOPATHY}

Retinal ischemia is involved in the occurrence of the two major complications of DR, namely DME and PDR. Surprisingly, little is known about the natural history of retinal ischemia in DR and how it is modified by treatment. Ischemia can affect different areas of the retina; its implications with regard to the development of 


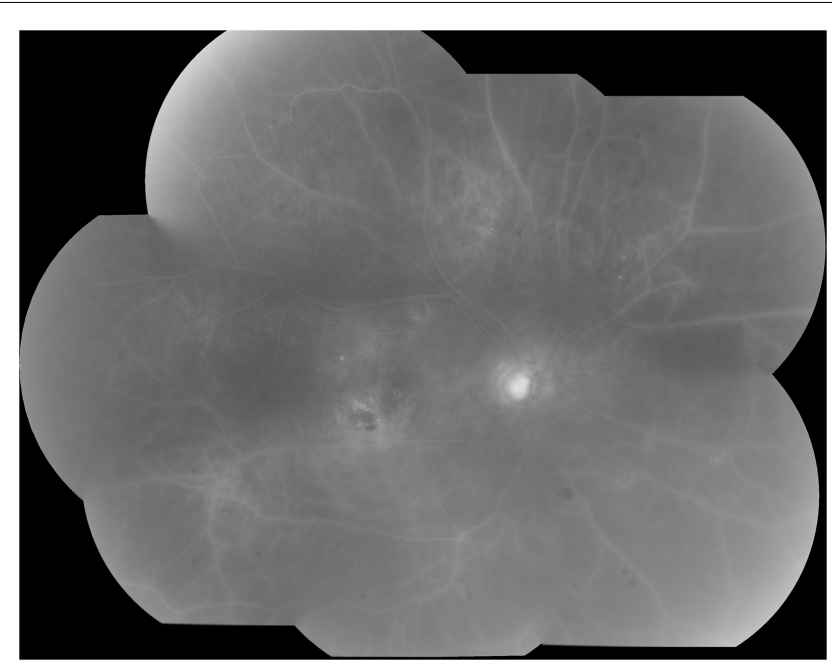

FIGURE 3 | Fluorescein angiography obtained from the right eye of a patient with non-proliferative diabetic retinopathy. Note diffuse retinal non-perfusion and ischemia in the midperipheral retina in the absence of neovascularization.

complications of DR may depend on this topographic distribution and also on its extension. For example, a relatively small area of ischemia affecting the perifoveal capillaries ("ischemic maculopathy") may have profound impact on vision. In contrast, a large area of midperipheral retinal ischemia may not produce an immediate change in sight but may trigger a neovascular response with development of PDR and poor longer term outcomes. In certain circumstances, very anterior (far peripheral) retinal ischemia, even if limited, may give rise to anterior segment neovascularization (rubeosis), including the development of neovascular glaucoma, and a more guarded prognosis. It is not clear why in some patients areas of retinal ischemia are mainly restricted to the macula, whereas in others the retinal vasculature is relatively intact at the macula but marked midperipheral retinal ischemia develops.

Clinically, retinal ischemia can be adequately identified, and its extension measured, by means of fundus fluorescein angiography (FFA) (Figure 3). For this imaging technique, a dye (fluorescein) is injected in a peripheral vein; images of the fundus are obtained as the dye circulates through the retinal blood vessels. Recently, new emerging technologies using wide-angle fundus cameras have become available $(26,27)$. These allow obtaining angiograms encompassing a 200-degree field of the retina in a single shot with a nearly complete visualization of the whole retinal vascular tree (Figure 4). Other new imaging techniques are being developed, such as differential phase-contrast swept-source optical coherence tomography (OCT), which allows visualization of retinal blood vessels without the need for injection of dyes (28-30).

Using FFA, spontaneous resolution of areas of retinal ischemia in DR has been observed (31), although the mechanisms underpinning re-perfusion have not been elucidated. Currently, no treatment has been identified that can reverse retinal ischemia in DR. For example, the current treatment for PDR, laser panretinal photocoagulation (PRP), aims at destroying the ischemic retina rather than at reperfusing it. Furthermore, progression of

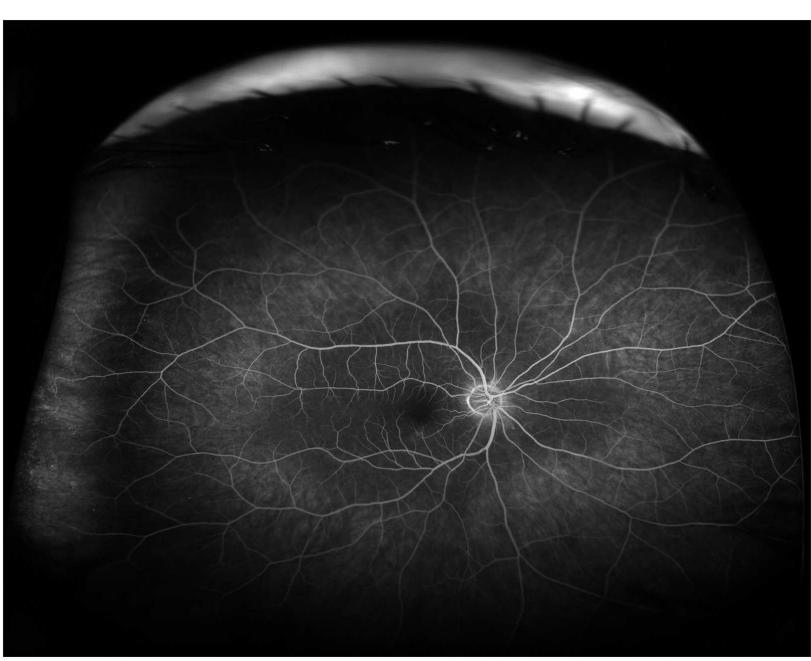

FIGURE 4 | Wide-angle fluorescein angiography obtained with the Optos imaging system. Note excellent visualization of the vascular tree in the posterior pole and midperipheral retina with a single short.

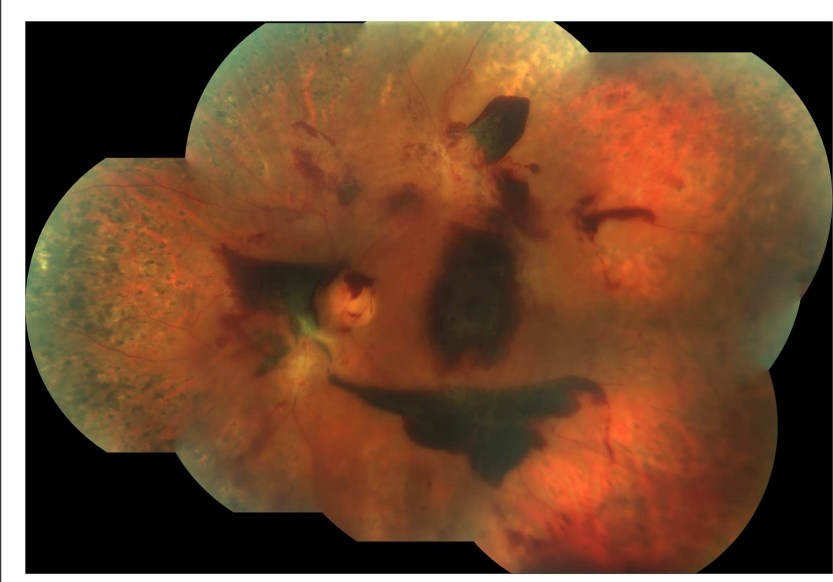

FIGURE 5 | Fundus photograph obtained from the left eye of a patient with proliferative diabetic retinopathy who had undergone laser panretinal photocoagulation (PRP). Despite a complete PRP, active disease was still present, as demonstrated by the presence of still viable neovascularization and extensive sub-hyaloid, pre-retinal hemorrhages. Note the large pre-retinal hemorrhage covering the fovea.

the disease can still be observed following PRP (Figure 5). As discussed below, circulating EPCs may play a role in vascular reperfusion and tissue regeneration. In addition, delivery of these cells has emerged as an exciting potential therapeutic strategy for retinal ischemia in DR.

\section{ENDOTHELIAL PROGENITOR CELLS}

Endothelial progenitor cells (EPCs) are circulating cells believed to play an important role in tissue regeneration by promoting the repair of blood vessels and aiding in the re-perfusion of ischemic areas (32). EPCs generally account for only $\sim 0.01 \%$ of circulating cells, although reported levels varied which may, once again, 
reflect on the variability on the cells measured (33). Their origin remains somewhat uncertain; they may derive from hematopoietic stem cells in the bone marrow and/or highly specialized vascular stem cell niches in vessel walls or within the endothelium (34, 35). Controversy also exists with regard to the definition of an EPC. Pre-clinical and clinical investigations evaluating the therapeutic potential of EPCs have produced variable results, with some studies showing favorable outcomes whereas others failed to demonstrate success (36-39). It is likely that this variable response observed in EPC therapy relates, at least in part, to the use of a heterogeneous mixture of cells (not just EPCs) rather than being explained by the lack of therapeutic potential of a well-defined, efficacious EPC sub-type.

EPCs have been proposed as useful cell biomarkers of disease (40). For both therapeutic and biomarker investigations to be successful, it is essential that well-defined populations of EPCs are used. It would be advantageous if agreement among researchers in the EPC field could be reached, especially with regard to the definition and terminology used to refer these cells and their various sub-types. If the same type of EPCs were to be used for therapeutic or prognostic purposes by researchers, comparisons among studies and pooling of their data, required to increase the power of the evidence, would be possible, furthering the research into this exciting area. As discussed below, unfortunately, this has not been the case so far with regard to the existing literature on EPCs in DR.

\section{DEFINING AN EPC}

Groundbreaking research by Asahara et al. (32) first isolated endothelial cell progenitors from human peripheral blood using CD34 and Flk-1 (VEGF receptor 2, VEGF-R2) surface markers. They determined that these cells were able to differentiate into endothelial cells and incorporate into sites where active angiogenesis was taking place. Subsequent studies by other groups provided supporting evidence on the existence of circulating EPCs (41-44).

As pointed above, controversy exists with regard to how to define an EPC. In a very recent article, Basile and Yoder thoroughly reviewed this issue and provided a useful perspective on the characterization of EPCs (45). They suggested that evidence support the concept that endothelial colony-forming cells (ECFC), also known as outgrowth endothelial cells (OECs), display many features of circulating cells that are consistent with the original criteria set for an EPC. Basile and Yoder proposed the term pro-angiogenic hematopoietic cells (PACs) to refer to cells that are not in-fact endothelial progenitors but rather "adjuvants" in the process of vascular repair. Our previously identified myeloid angiogenic cells (MACs) would also fit with this definition. Thus, it is likely that different populations of adjuvants cells may exist (see below). The term "EPC" should not be used, hence, to refer PACs/MACs but be restricted to true EPCs (for many researchers, ECFCs).

ECFCs are retrieved with greater efficiency from cord blood compared with peripheral blood; indeed, the former source provides cells with higher proliferation rates and achieves significantly more population doublings than those from peripheral blood (46). A standard method for obtaining ECFCs is by in vitro culturing of the mononuclear fraction of blood at high density on Type 1 collagen-coated plates (47). Using this technique and depending on whether they are isolated from cord blood or peripheral
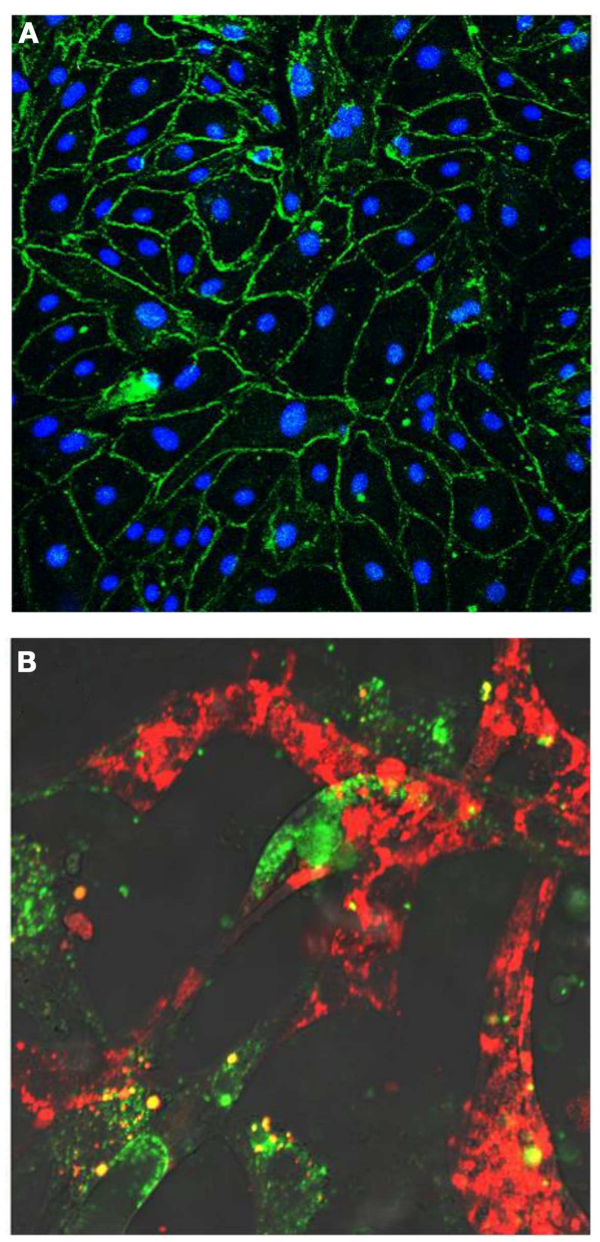

FIGURE 6 | (A) Human endothelial colony-forming cells (ECFCs) grow in culture as a cell monolayer and disclose a cobblestone appearance. Cells form tight junctional complexes, shown by Z0-1 staining in green. Nuclei labeled in blue with DAPI. (B) Human endothelial colony-forming cells (ECFCs) (labeled in red) form tube-like structures with retinal microvascular endothelial cells (labeled in green) in a 3D Matrigel in vitro model.

blood, ECFCs colonies appear between 2 and 5 weeks and display a characteristic cobblestone-shaped morphology (Figure 6) (47). Research from our group using genome-wide transcriptomics, proteomics, and ultrastructural evaluation has demonstrated ECFCs intrinsic endothelial identity $(48,49)$. ECFCs have a remarkably high proliferative capacity in comparison with mature endothelial cells and maintain an endothelial phenotype with ex vivo long-term expansion (49). ECFCs have robust clonogenic potential, high telomerase activity, and in vitro and in vivo vessel formation ability (45). Single-cell cloning of ECFCs demonstrates a hierarchic regenerative potential with cells of high proliferative potential (HPP) and low proliferative potential (LPP) similar to what has been observed in hematopoietic stem cells $(34,44)$. Ingram et al. (44) previously demonstrated that cord blood-derived ECFCs possessed greater HPP (with concomitant enhancement of telomerase activity) than ECFCs isolated from peripheral blood. If ECFCs are to be utilized for regenerative 
medicine, it may be advantageous to isolate and use an ECFC sub-population with HPP in order to achieve maximum cell number expansion, if required.

ECFCs are positive for a range of endothelial cell markers, including VEGF-R2, VE-cadherin (CD144), CD31, CD105, CD146, and Tie2; negative for hematopoietic cell markers such as CD45, CD14, CD133, CD115, and demonstrate variable positivity to CD34 and CD117 (45, 50). Although evaluation of EPCs has been undertaken widely using a combination of the above cell markers by flow cytometry, as there is no specific antigen for ECFCs, in vivo and in vitro functional evaluations are required to identify specifically these cells. Thus, studies using only flow cytometry would be determining "putative" EPCs.

In contrast to ECFCs, PACs are $\mathrm{CD} 34^{+} \mathrm{CD} 45^{+} \mathrm{CD} 133^{+} \mathrm{CD} 31^{+}$ CD14- ${ }^{-}$D235a ${ }^{-}$(45). Although circulating PACs may localize in a peri-vascular manner at sites of vascular injury, they are not able to integrate in the blood vessels as proper endothelial cells (45). PACs have LPP but they do appear to contribute to vascular repair by paracrine secretion of vasoactive molecules. Similar to PACs, MACs do not populate vessel walls but are pro-angiogenic. MACs are $\mathrm{CD}_{4}{ }^{+} \mathrm{CD} 14^{+} \mathrm{CD} 8^{+} \mathrm{CD} 163^{+} \mathrm{Tie}^{-}, \mathrm{CD} 209^{-} \mathrm{CD}^{-} 6^{-}$ (51). Therefore, as much of the previously conducted work on "EPCs" was undertaken using cells that may not have fit strictly with the above definition of an ECFC and may have been only characterized by flow cytometry, data summarized below should be interpreted with caution.

\section{FUNCTIONAL PROPERTIES OF EPCS AND MODULATORY MECHANISMS}

Functionally, EPCs present characteristics of endothelial cells (50). Earlier studies emphasized the in vitro angiogenic potential of EPCs, their ability to integrate into pre-existing vessels and de novo tube formation $(32,43)$. Furthermore, several research groups, including our own, have demonstrated that EPCs possess in vivo potential for direct engraftment, aiding vascular repair and forming well-perfused vasculature in various in vivo models $(32,43)$. For example, the therapeutic potential of EPCs to treat retinal ischemia following intravitreal injection was shown in a mouse model of ischemic retinopathy in which ECFCs homed specifically to ischemic retina and integrated directly within the host vasculature (50). Importantly, these cells assisted in vascular remodeling by forming vascular tubes with subsequent reduction in the area of retinal ischemia and a concomitant increase in normal vasculature (50).

In response to hypoxia, EPCs have the ability to mobilize from their resident niche into the circulating blood and home to ischemic tissues. The mechanisms by which EPCs mobilize and specifically home to areas of ischemia are highly complex and incompletely understood. They involve a range of pathways and stimulatory factors such as EPO (52), VEGF (53), and G-CSF (54) but it also appears that signals released from apoptotic endothelial cells are important for EPC recruitment to sites of vascular damage (55). Since the homing process is hypoxiamediated, it is unsurprising that HIF- $1 \alpha$ appears to be crucial for EPC recruitment to sites of vascular insufficiency (56). On sensing low oxygen levels, HIF-1 $\alpha$ induces transcription of SDF1 and its receptor CXCR4, these known to be essential for EPC migration and adhesion to specific areas of ischemic damage (56).
Blocking the CXCR4/SDF-1 signaling pathway inhibits EPC homing and results in their attenuated participation in promoting vascularization (57).

Several factors appear to influence the occurrence and circulating levels of EPCs. These include age (58) and gender (59) with younger women having higher numbers of EPCs. Physical activity also increases numbers of EPCs, especially intense exercise (60). A circadian rhythm on EPC release has been identified with higher levels of EPCs circulating in the morning than in the evening (61). Hypertension, diabetes, smoking habits as well as medications, including statins, angiotensin-converting enzyme inhibitors, and insulin may also affect the production and release of these cells into the circulation $(40,62)$.

\section{EPCS IN DIABETES AND DIABETIC RETINOPATHY}

Accumulating evidence supports the concept that both type 1 and type 2 diabetic patients have altered numbers of circulating EPCs (63-65) and, when isolated, show dysfunctional responses including impaired vasoreparative potential and premature senescence $(65,66)$. Conflicting results, however, have been reported with regard to the levels of circulating EPCs in people with diabetes. Thus, reduced $(63)$, increased $(67)$, or unchanged $(68,69)$ levels of EPCs compared with those observed in healthy age-matched volunteers have been found in previous studies using flow cytometry techniques. Similarly, although a reduced potential for EPCs to grow in cultures derived from monocytes obtained from peripheral blood was found by some investigators $(64,65,70)$, others observed enhanced growth potential when EPCs were isolated from diabetic patients with PDR (67) (see below). Poor glycemic control, as determined by $\mathrm{HbA} 1_{\mathrm{c}}$ levels, appears to be associated with a reduction in numbers of circulating EPCs whereas an adequate control of glycemia seems to increase their numbers (64). Beyond the presence of diabetes, a relatively scarce number of studies have been conducted evaluating EPCs specifically in patients with DR (Table 1) (67-69, 71-74). A summary of these follows.

\section{Clinical studies on EPCs and DR}

In a cross-sectional study including 60 type 2 diabetic patients with and without peripheral arterial disease and with and without severe NPDR and PDR $\left(\mathrm{DR}^{-} / \mathrm{PAD}^{-} n=15, \mathrm{DR}^{-} / \mathrm{PAD}^{+} n=30\right.$, $\mathrm{DR}^{+} / \mathrm{PAD}^{-} n=5$, and $\mathrm{DR}^{+} / \mathrm{PAD}^{+} n=10$ ), Fadini and collaborators (69) identified reduced levels of $\mathrm{CD} 34^{+}$cells in patients with DR when compared with those without it. No differences in levels of $\mathrm{CD}_{3} 4^{+} / \mathrm{KDR}^{+}(\mathrm{KDR}=\mathrm{VEGF}-\mathrm{R} 2)$ cells between these groups were, however, found. Patients with peripheral arterial disease had reduced levels of $\mathrm{CD} 34^{+} / \mathrm{KDR}^{+}$cells.

Lee and colleagues (73) evaluated, in a cross-sectional study, the concentration of circulating EPCs, defined as $\mathrm{CD}^{+} 4^{+}$cells or c-Kit ${ }^{+}$cells, in a group of 45 type 2 diabetic patients and compared them with those observed in 15 age- and gendermatched control subjects. Patients were classified as having no DR $(n=15)$, NPDR $(n=15)$, or PDR $(n=15)$. Circulating CD34 ${ }^{+}$ cell numbers were higher in diabetic patients compared with control subjects and increase with increasing staging of the disease $(\mathrm{PDR}>\mathrm{NPDR}>$ no DR).

Brunner and collaborators (71) undertook a case-control cross-sectional study, which included 90 patients with type 1 


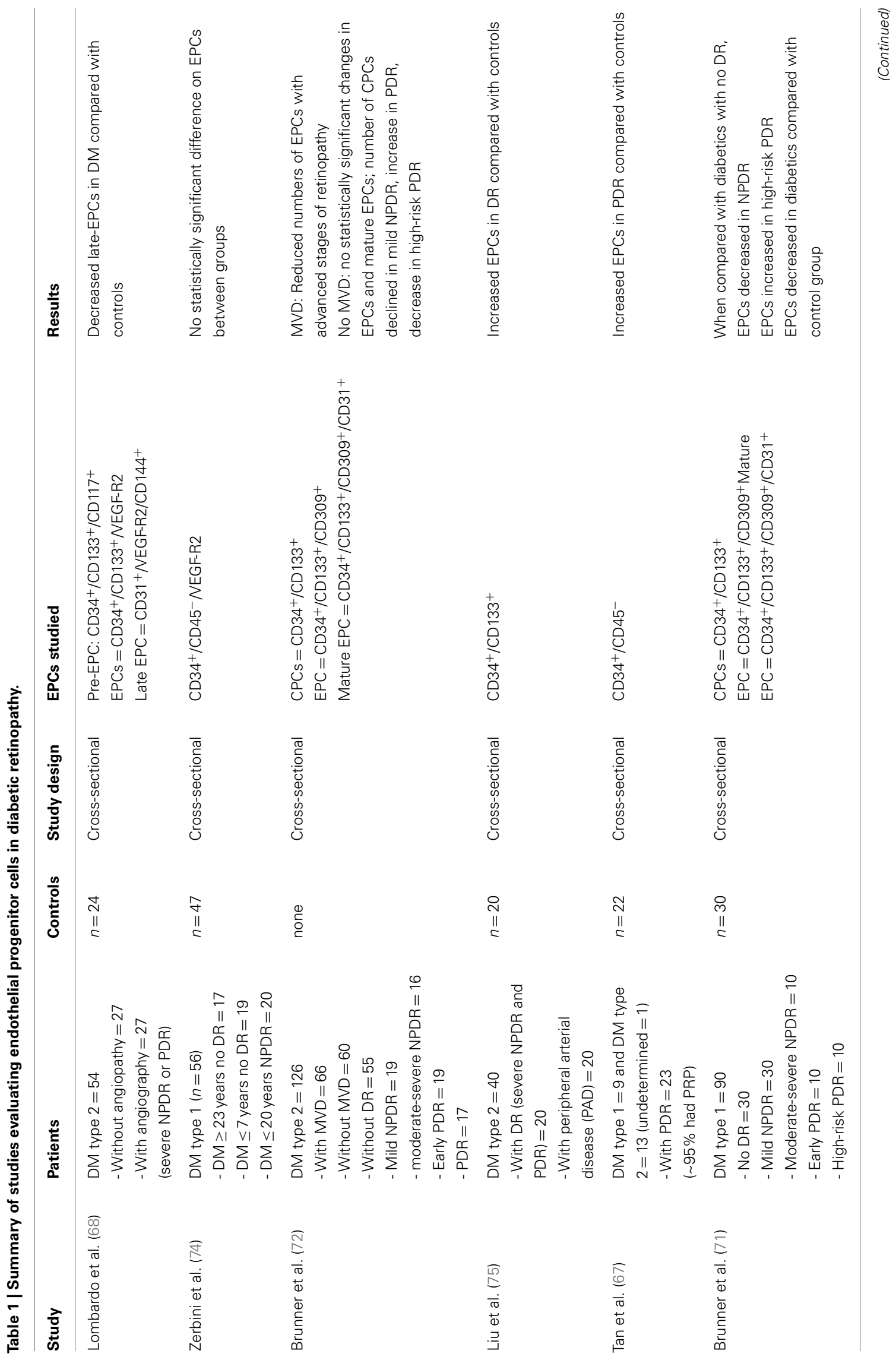




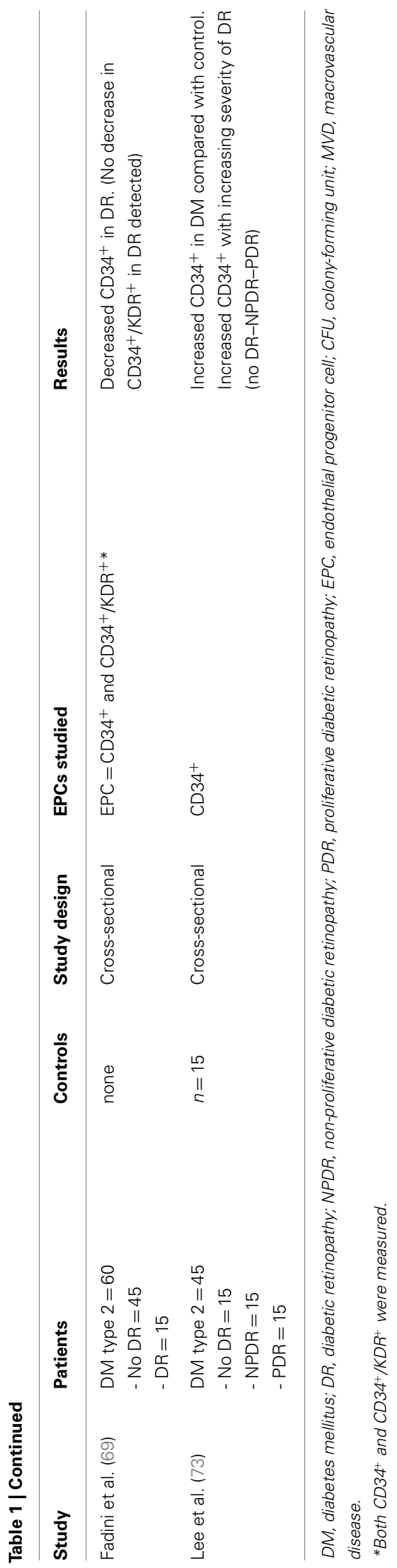

$\mathrm{DM}$ with no $\mathrm{DR}(n=30)$, mild $\operatorname{NPDR}(n=30)$, moderate to severe $\operatorname{NPDR}(n=10)$, mild to moderate $\operatorname{PDR}(n=10)$, and high-risk PDR $(n=10)$. The study included an age-, gender-, and body-mass index-matched control group $(n=30)$. $\mathrm{CD} 34^{+} / \mathrm{CD} 133^{+}$(which they labeled "circulating progenitor cells" or "CPCs"), CD $34^{+} / \mathrm{CD} 133^{+} / \mathrm{CD} 309^{+}$(labeled as "EPCs"), and $\mathrm{CD} 34^{+} / \mathrm{CD} 133^{+} / \mathrm{CD} 309^{+} / \mathrm{CD} 31^{+}$(labeled as "mature EPCs" of "mat-EPCs") were measured. When compared with diabetic patients without DR, levels of CPCs, EPCs, and mat-EPCs were found to be reduced in NPDR; EPCs and mat-EPCs were found to be increased in PDR. EPC and mat-EPC number was reduced in patients with diabetes when compared with healthy subjects. As a more recent follow-up, this group expanded their observations to a group of 126 patients with type 2 diabetes, with or without macrovascular disease and with no DR $(n=55)$, mild NPDR $(n=19)$, moderate to severe NPDR $(n=16)$, early PDR $(n=19)$, and high-risk PDR $(n=17)$ (72). In contrast to their previous findings, they failed to detect statistically significant differences in EPC numbers in patients with type 2 diabetes without macrovascular disease at different stages of DR. However, in patients with macrovascular disease, EPCs declined with advancing stages of retinopathy.

Liu and colleagues (75) examined type 2 diabetic patients with DR (severe NPDR and PDR, $n=20$ ), type 2 diabetic patients with peripheral arterial disease $(n=20)$, and healthy age- and gendermatched volunteers (control group, $n=20$ ) and found increased levels of circulating EPCs in patients with DR when compared with the control group. EPCs were defined as $\mathrm{CD} 133^{+} / \mathrm{CD} 34^{+}$ cells, as determined by flow cytometry. An increase in early EPCCFU (colony-forming units) count was also observed in patients with DR. Serum levels of nerve growth factor (NGF) and brainderived neurotrophic factor (BDNF) were found to be increased in patients with DR and correlated with levels of circulating EPCs.

Tan and collaborators (67) undertook a study on a group of 23 diabetic patients, type $1(n=9)$ and type $2(n=13)$ ( $n=1$ not determined) with PDR and 22 healthy controls. The great majority of patients (95\%) had received PRP. They found that the number of circulating ECFCs, determined as $\mathrm{CD} 34^{+} / \mathrm{CD} 45^{-}$cells by flow cytometry, was increased in PDR. Furthermore, mononuclear cells obtained from patients who had PDR were more likely to grow ECFC colonies in culture than those obtained from healthy controls. ECFCs from patients with $\mathrm{PDR}$ demonstrated reduced migration ( $\operatorname{PDR} n=2)$ and reduced incorporation into vascular tubes (PDR $n=3$ ) in vitro. Microarray analysis of ECFCs from patients with PDR $(n=2)$ demonstrated up-regulation of thrombospondin-1 and tissue inhibitor of matrix metalloproteinases-3 (TIMP-3); western blotting confirmed increased levels of both proteins in ECFC lysates.

Lombardo and associates (68) did not find a significant reduction in the number of EPCs $\left(\mathrm{CD} 34^{+} / \mathrm{CD} 133^{+} / \mathrm{VEGF}-\right.$ $\mathrm{R} 2^{+}$) in patients with type 2 diabetes when compared with those from a group of healthy individuals (control group). Subsets of patients with diabetes with or without angiopathy were found to have significantly higher numbers of what was termed pre-EPCs $\left(\mathrm{CD} 34^{+} / \mathrm{CD} 133^{+} / \mathrm{CD} 117^{+}\right)$. However, numbers of $\mathrm{CD} 1^{+} / \mathrm{VEGF}-\mathrm{R} 2^{+} / \mathrm{VE}-\mathrm{cadherin}{ }^{+}$cells $\left(\mathrm{CD} 144^{+}\right)$, termed by the 
authors "late-EPCs," were reduced in patients with diabetes type 2 recently diagnosed (within 1 year of diagnosis) with no clinical evidence of angiopathy $(n=27)$ and in those with peripheral arterial occlusive disease and DR (severe NPDR or PDR) $(n=27)$ when compared with the control group $(n=24)$. The number of circulating endothelial cells, matured endothelial cells thought to sloughed off from the vascular intima, where increased in diabetic patients.

Zerbini and colleagues (74) evaluated three groups of type 1 diabetics, with long-standing ( $\geq 23$ years; $n=17$ ) and shortstanding ( $\leq 7$ years; $n=19$ ) diabetes and no retinopathy and with NPDR (diabetes of $\leq 20$ years standing; $n=20$ ). A group of ageand gender-matched healthy volunteers were also included for each of the above (with $n=17,12$, and 18 subjects, respectively). No differences were found in levels of CD45-/CD34+/VEGF$\mathrm{R}^{+}{ }^{+}$cells between the above different groups studied. However, the number of colonies formed in the Hill assay was increased in patients with NPDR when compared with those in the control group. Patients with milder retinopathy tended to form more colonies than patients with more severe retinopathy. In patients with long-standing diabetes and no retinopathy, the colony counts were similar to those in control subjects.

The interpretation of the previously presented findings is challenging. For instance, both high $(67,71)$ and low $(69,72)$ levels of circulating EPCs have been reported in patients with severe NPDR and PDR when compared with those in individuals with no or mild retinopathy and with healthy subjects without DM. It is possible that discrepancies observed may relate to methodological differences among studies, specifically, and as underlined above, the different criteria used to define an EPC. Other factors need to be taken into consideration. Some studies included small number of subjects (67-69, 73-75), especially when grouped in the different disease progression categories (68, 71-75), which may have had an effect on the statistical evaluation of the data (a sample power calculation was not given in any of the above studies). All published studies on the subject have been cross-sectional $(67-69,74,75)$ and, subsequently, truly unable to evaluate the influence of changes in EPCs in relation to disease progression. Few addressed the relationship between number/function of EPCs and severity of DR (71-73) and none attempted to relate them to the presence/extension of retinal ischemia, as determined by using imaging modalities such as fluorescein angiography. As retinal ischemia would seem to be a main driver for eliciting a vasoregenerative response led by EPCs, correlating the latter with retinal ischemia would seem fundamental. In this regard, prospective longitudinal studies from our own laboratory are underway to address the relationship between retinal ischemia and the EPC response. As information with regard to flow cytometry techniques used in these studies was limited, variability in methodological aspects of flow cytometry could have also accounted for inconsistencies in the results observed.

\section{POTENTIAL USE OF EPCS IN DIABETIC RETINOPATHY}

Endothelial progenitor cells could be potentially used in the management of patients with DR with two different purposes: (1) as cell biomarkers or "prognosticators" and (2) as a potential therapy.

\section{EPCs AS BIOMARKERS OF DISEASE SEVERITY}

Endothelial progenitor cells have been proposed as useful biomarker for cardiovascular events and cancer progression $(76,77)$. In a similar manner, it is possible that EPC number/function could be used to predict which individuals may be at higher risk of losing sight from DME or PDR. Prospective adequately powered cohort studies would be needed to elucidate the potential use of EPCs as cell biomarkers for DME and PDR and take into account other risk factors and variables known to potentially affect retinopathy. It is possible that other cells besides those strictly defined as EPCs (for many, ECFCs) may be used for this purpose. As identification of ECFCs in culture requires a period of around 4-6 weeks, this strategy may be less practical and appealing than evaluating levels of other circulating cell types by flow cytometry. Research in this area could prove fruitful as predicting individuals at higher risk of visual loss would be extremely helpful to the currently overstretched DR screening programs and health care systems. This would allow a personalized follow-up strategy based on the individual's risk of progression and would avoid close follow-up with the benefit to patients and health care systems.

\section{EPCS AS A POTENTIAL THERAPY TO TREAT DR}

The potential use of EPCs to treat DR is exciting but extensive work is required before they could be introduced in clinical practice. Firstly, the type of cell(s) to be used and the number of cells required should be determined. If a cell, alone, were to be used for therapeutic purposes, those with the highest reparative potential (i.e., ECFCs) may be chosen. Although not the subject of this review, pericyte progenitor cells (PPCs) have been recently recognized $(78,79)$. As both, endothelial cells and pericytes are affected in DR, it would seem reasonable to consider the possible administration of both progenitors in order to treat this vascular disorder. Recently, Lee and co-workers (80) demonstrated that $\mathrm{CD} 34^{-}$cells may modulate the inherent characteristics and behavior of ECFCs. They showed in vitro that ECFCs arising from cultures in which $\mathrm{CD} 34^{+}$and $\mathrm{CD} 34^{-}$cells are present (to which they referred to as "hybrid ECFCs") have higher proliferation capacity and slower senescence than those ECFCs grown in cultures lacking CD34- cells (which they referred to as stemECFCs). The later, however and importantly, demonstrated higher endothelial cell differentiation. Both cell types (hybrid ECFCs and stem-ECFCs), expressed ECFC surface markers, including CD133, VEGF-R2, CXCR4, and c-kit) but did not expressed hematopoietic lineage markers (CD11b, CD14, CD45). Before CD34- cells are used to condition ECFCs prior to treatment (80) it would be important to determine that these ECFCs do not have an increased ability to form "neovessels." Whereas in other organs "neovascularization" may be beneficial, for instance in the heart, this would not be the case in the retina where "revascularization" or "healing" of pre-existing blood vessels rather than neovascularization should be sought. Other cells may be also considered. As PACs are likely to act as adjuvants in the process of "vascular regeneration," further consideration to administering these, in addition, should be given. However, the possibility for PACs to develop into pro-inflammatory cells, which could have potentially a deleterious effect in the retina, should be cautiously balanced. 
Secondly, the number of cells required would need to be estimated. It is likely that it would depend on the route of administration selected as well as on the stage of disease at which patients are planned to be treated. The route of administration will need to be carefully chosen. Local delivery into the eye by means of intravitreal injections would be an option, as many clinical trials (81-84) using anti-VEGF therapy (Ranibizumab, Bevacizumab, and Aflibercept) have demonstrated their safety even when administered monthly. However, considering the fact that DR often affects similarly both eyes and that DM is a systemic disorder in which other organs besides the eye are affected and may benefit from this therapy, systemic administration should not be ruled out. Systemic administration, if safe, could be given repeatedly, if required, and at an early stage of disease.

Thirdly, the population most likely to benefit from treatment with EPCs should be defined. EPCs could be used in an attempt to re-vascularize areas of retinal ischemia in patients who have already developed retinal vessel dropout as determined by fluorescein angiography. They could be used also to improve retinal vessel function in patients with increase vessel permeability and subsequent DME with or without retinal ischemia being present. If the balance between beneficial effects and side effects were to be appropriate, EPCs could be used even at very early stages of retinopathy, before marked retinal vessel abnormalities occurred in an attempt to abort progression to sight threatening complications. Alternatively, maneuvers aimed at increasing levels of circulating endogenous EPCs, by stimulation of the bone marrow and other EPC niches, and their homing to sites where needed (i.e., retina) would be an appealing option.

Fourthly, the most appropriate outcome measures that would allow treatment effects to be determined in clinical trials should be sought. For instance, if ECFCs adequately incorporate into damaged retinal blood vessels in ischemic retina oxygen levels in retinal veins may be expected to drop, as it has been shown that there is increased oxygen saturation in people with DR (85, 86), which may relate, at least partially, by the poor distribution of blood to retinal tissue result of capillary dropout. Fluorescein angiography and, in the future, when fully developed for clinical use, differential phase-contrast swept-source OCT may be able to provide adequate information with regard to ECFCs incorporation to retinal vessel walls by demonstrating the presence of capillaries in retinal areas were prior to treatment were not present and, in the case of the former, by demonstrating improve circulation in previously ischemic areas. Retinal functional studies, such as multifocal ERG responses, may be able to determine improved responses in those areas where revascularization takes place.

Lastly but importantly, potential side effects of the treatment will need to be carefully evaluated. Data from available completed clinical trials, however, suggests that ECFCs should be safe for clinical use.

\section{CONCLUSION}

Available data suggests EPCs are essential on maintaining retinal vessel integrity and homeostasis. While some patients seem to have inherent regenerative capacity, the molecular and cellular basis for this has not been demonstrated. It seems likely that high levels of reparative cells could underpin less risk of DR progression. However, the precise role of EPCs in DR remains to be determined. Experimental and adequately powered prospective cohort clinical studies are required to better understand the possible role of EPCs in the occurrence and progression of this disease. The possibility of using EPCs as cell biomarkers of the sight threatening complications of DR, namely DME and PDR and as cell therapy is an exciting one. Given the complexity of DM and DR, with multiple factors modulating disease progression, a joint effort by multidisciplinary research teams is likely to be needed in order to achieve this goal.

\section{ACKNOWLEDGMENTS}

The authors would like to thank Ms Anne Ramsey for her invaluable expertise obtaining the images that illustrate this manuscript.

\section{REFERENCES}

1. Kocur I, Resnikoff S. Visual impairment and blindness in Europe and their prevention. Br J Ophthalmol (2002) 86:716-22. doi:10.1136/bjo.86.7.716

2. Resnikoff S, Pascolini D, Etya'ale D, Kocur I, Pararajasegaram R, Pokharel GP, et al. Global data on visual impairment in the year 2002. Bull World Health Organ (2004) 82:844-51. doi:10.1590/S0042-96862004001100009

3. Zheng Y, He M, Congdon N. The worldwide epidemic of diabetic retinopathy. Indian J Ophthalmol (2012) 60:428-31. doi:10.4103/0301-4738.100542

4. Fong DS, Aiello LP, Ferris FL III, Klein R. Diabetic retinopathy. Diabetes Care (2004) 27:2540-53. doi:10.2337/diacare.27.10.2540

5. Group UK. Prospective Diabetes Study. Tight blood pressure control and risk of macrovascular and microvascular complications in type 2 diabetes: UKPDS 38. BMJ (1998) 317:703-13. doi:10.1136/bmj.317.7160.703

6. Vigstrup J, Mogensen C. Proliferative diabetic retinopathy: at risk patients identified by early detection of microalbuminuria. Acta Ophthalmol (1985) 63:530-4. doi:10.1111/j.1755-3768.1985.tb05240.x

7. Chen Y, Chen H, Tarng D. More impact of microalbuminuria on retinopathy than moderately reduced GFR among type 2 diabetic patients. Diabetes Care (2012) 35:803-8. doi:10.2337/dc11-1955

8. Jenkins A, Rowley K, Lyons T, Best J, Hill M, Klein R. Lipoproteins and diabetic microvascular complications. Curr Pharm Des (2004) 10:3395-418. doi: $10.2174 / 1381612043383188$

9. Lyons TJ, Jenkins AJ, Zheng D, Lackland DT, McGee D, Garvey WT, et al. Diabetic retinopathy and serum lipoprotein subclasses in the DCCT/EDIC cohort. Invest Ophthalmol Vis Sci (2004) 45:910-8. doi:10.1167/iovs.02-0648

10. DCCT Research Group. Diabetes control and complications trial (DCCT): the effect of intensive treatment of diabetes on the development and progression of long-term complications in insulin dependent diabetes mellitus. $\mathrm{N} \mathrm{Engl} \mathrm{J} \mathrm{Med}$ (1993) 329:977-86. doi:10.1056/NEJM199309303291401

11. Hirsch IB, Brownlee M. Beyond hemoglobin Alc - need for additional markers of risk for diabetic microvascular complications. JAMA (2010) 303:2291-2. doi:10.1001/jama.2010.785

12. Klein R, Knudtson MD, Lee KE, Gangnon R, Klein BEK. The Wisconsin epidemiologic study of diabetic retinopathy XXII: the twenty-five-year progression of retinopathy in persons with type 1 diabetes. Ophthalmology (2008) 115(11):1859-68. doi:10.1016/j.ophtha.2008.08.023

13. West S, Groves D, Lipinski H, Nicoll D, Mason R, Scanlon P, et al. The prevalence of retinopathy in men with type 2 diabetes and obstructive sleep apnoea. Diabet Med (2010) 27:423-30. doi:10.1111/j.1464-5491.2010.02962.x

14. Rudrappa S, Warren G, Idris I. Obstructive sleep apnoea is associated with the development and progression of diabetic retinopathy, independent of conventional risk factors and novel biomarkers for diabetic retinopathy. BrJOphthalmol (2012) 96:1535-6. doi:10.1136/bjophthalmol-2012-301991

15. Arnold E, Rivera JC, Thebault S, Moreno-Páramo D, Quiroz-Mercado H, Quintanar-Stéphano A, et al. High levels of serum prolactin protect against diabetic retinopathy by increasing ocular vasoinhibins. Diabetes (2010) 59:3192-7. doi:10.2337/db10-0873 
16. Zietz B, Buechler C, Kobuch K, Neumeier M, Schölmerich J, Schäffler A. Serum levels of adiponectin are associated with diabetic retinopathy and with adiponectin gene mutations in Caucasian patients with diabetes mellitus type 2 . Exp Clin Endocrinol Diabetes (2008) 116:532-6. doi:10.1055/s-2008- 1058086

17. Nguyen TT, Alibrahim E, Islam FA, Klein R, Klein BE, Cotch MF, et al. Inflammatory, hemostatic, and other novel biomarkers for diabetic retinopathy the multi-ethnic study of atherosclerosis. Diabetes Care (2009) 32:1704-9. doi: $10.2337 / \mathrm{dc} 09-0102$

18. Lakhani E, Wright T, Abdolell M, Westall C. Multifocal ERG defects associated with insufficient long-term glycemic control in adolescents with type 1 diabetes. Invest Ophthalmol Vis Sci (2010) 51:5297-303. doi:10.1167/iovs.10-5200

19. Shimada Y, Li Y, Bearse MA, Sutter EE, Fung W. Assessment of early retinal changes in diabetes using a new multifocal ERG protocol. $\mathrm{Br} J$ Ophthalmol (2001) 85:414-9. doi:10.1136/bjo.85.4.414

20. Mandecka A, Dawczynski J, Vilser W, Blum M, Müller N, Kloos C, et al. Abnormal retinal autoregulation is detected by provoked stimulation with flicker light in well-controlled patients with type 1 diabetes without retinopathy. Diabetes Res Clin Pract (2009) 86:51-5. doi:10.1016/j.diabres.2009.06.017

21. Curtis T, Gardiner T, Stitt A. Microvascular lesions of diabetic retinopathy: clues towards understanding pathogenesis? Eye (2009) 23:1496-508. doi:10.1038/eye. 2009.108

22. Adamis AP, Miller JW, Bernal M, D’Amico DJ, Folkman J, Yeo T, et al. Increased vascular endothelial growth factor levels in the vitreous of eyes with proliferative diabetic retinopathy. Am J Ophthalmol (1994) 118:445-50.

23. Miller JW, Adamis AP, Shima DT, D'Amore PA, Moulton RS, O'Reilly MS, et al. Vascular endothelial growth factor/vascular permeability factor is temporally and spatially correlated with ocular angiogenesis in a primate model. Am J Pathol (1994) 145:574-84.

24. Sharma N, Gardiner T, Archer D. A morphologic and autoradiographic study of cell death and regeneration in the retinal microvasculature of normal and diabetic rats. Am J Ophthalmol (1985) 100:51-60.

25. Linskens MH, Harley CB, West MD, Campisi J, Hayflick L. Replicative senescence and cell death. Science (1995) 267:13.

26. Wessel MM, Nair N, Aaker GD, Ehrlich JR, D'Amico DJ, Kiss S. Peripheral retinal ischaemia, as evaluated by ultra-widefield fluorescein angiography, is associated with diabetic macular oedema. Br J Ophthalmol (2012) 96:694-8. doi:10.1136/bjophthalmol-2011-300774

27. Wessel MM, Aaker GD, Parlitsis G, Cho M, D’Amico DJ, Kiss S. Ultra-wide-field angiography improves the detection and classification of diabetic retinopathy. Retina (2012) 32:785-91. doi:10.1097/IAE.0b013e3182278b64

28. Motaghiannezam SR, Koos D, Fraser SE. Differential phase-contrast, sweptsource optical coherence tomography at $1060 \mathrm{~nm}$ for in vivo human retinal and choroidal vasculature visualization. J Biomed Opt (2012) 17:026011. doi:10.1117/1.JBO.17.2.026011

29. Kim DY, Fingler J, Zawadzki RJ, Park SS, Morse LS, Schwartz DM, et al. Optical imaging of the chorioretinal vasculature in the living human eye. Proc Natl Acad Sci U S A (2013) 110:14354-9. doi:10.1073/pnas.1307315110

30. Yasuno Y, Hong Y, Makita S, Yamanari M, Akiba M, Miura M, et al. In vivo highcontrast imaging of deep posterior eye by $1-\mu \mathrm{m}$ swept source optical coherence tomography and scattering optical coherence angiography. Opt Express (2007) 15:6121-39. doi:10.1364/OE.15.006121

31. Takahashi K, Kishi S, Muraoka K, Shimizu K. Reperfusion of occluded capillary beds in diabetic retinopathy. Am J Ophthalmol (1998) 126:791-7. doi:10.1016/ S0002-9394(98)00242-6

32. Asahara T, Murohara T, Sullivan A, Silver M, van der Zee R, Li T, et al. Isolation of putative progenitor endothelial cells for angiogenesis. Science (1997) 275:964-7. doi:10.1126/science.275.5302.964

33. Khoo CP, Pozzilli P, Alison MR. Endothelial progenitor cells and their potential therapeutic applications. Regen Med (2008) 3:863-76. doi:10.2217/17460751.3. 6.863

34. Yoder MC, Mead LE, Prater D, Krier TR, Mroueh KN, Li F, et al. Redefining endothelial progenitor cells via clonal analysis and hematopoietic stem/progenitor cell principals. Blood (2007) 109:1801-9. doi:10.1182/blood2006-08-043471

35. Ingram DA, Mead LE, Moore DB, Woodard W, Fenoglio A, Yoder MC. Vessel wall-derived endothelial cells rapidly proliferate because they contain a complete hierarchy of endothelial progenitor cells. Blood (2005) 105:2783-6. doi:10.1182/blood-2004-08-3057
36. Kawamoto A, Katayama M, Handa N, Kinoshita M, Takano H, Horii M, et al. Intramuscular transplantation of G-CSF-Mobilized CD34 cells in patients with critical limb ischemia: a phase I/IIa, multicenter, single-blinded, dose-escalation clinical trial. Stem Cells (2009) 27:2857-64. doi:10.1002/stem.207

37. Assmus B, Honold J, Schächinger V, Britten MB, Fischer-Rasokat U, Lehmann R, et al. Transcoronary transplantation of progenitor cells after myocardial infarction. N Engl J Med (2006) 355:1222-32. doi:10.1056/NEJMoa051779

38. Beitnes JO, Hopp E, Lunde K, Solheim S, Arnesen H, Brinchmann JE, et al. Longterm results after intracoronary injection of autologous mononuclear bone marrow cells in acute myocardial infarction: The ASTAMI randomised, controlled study. Heart (2009) 95:1983-9. doi:10.1136/hrt.2009.178913

39. Janssens S, Dubois C, Bogaert J, Theunissen K, Deroose C, Desmet W, et al. Autologous bone marrow-derived stem-cell transfer in patients with ST-segment elevation myocardial infarction: double-blind, randomised controlled trial. Lancet (2006) 367:113-21. doi:10.1016/S0140-6736(05)67861-0

40. Vasa M, Fichtlscherer S, Aicher A, Adler K, Urbich C, Martin H, et al. Number and migratory activity of circulating endothelial progenitor cells inversely correlate with risk factors for coronary artery disease. Circ Res (2001) 89:E1-7. doi:10.1161/hh1301.093953

41. Hur J, Yoon C, Kim H, Choi J, Kang H, Hwang K, et al. Characterization of two types of endothelial progenitor cells and their different contributions to neovasculogenesis. Arterioscler Thromb Vasc Biol (2004) 24:288-93. doi:10.1161/01.ATV.0000114236.77009.06

42. Rehman J, Li J, Orschell CM, March KL. Peripheral blood "endothelial progenitor cells" are derived from monocyte/macrophages and secrete angiogenic growth factors. Circulation (2003) 107:1164-9. doi:10.1161/01.CIR. 0000058702.69484.A0

43. Reinisch A, Hofmann NA, Obenauf AC, Kashofer K, Rohde E, Schallmoser K, et al. Humanized large-scale expanded endothelial colony-forming cells function in vitro and in vivo. Blood (2009) 113:6716-25. doi:10.1182/blood-200809- 181362

44. Ingram DA, Mead LE, Tanaka H, Meade V, Fenoglio A, Mortell K, et al. Identification of a novel hierarchy of endothelial progenitor cells using human peripheral and umbilical cord blood. Blood (2004) 104:2752-60. doi:10.1182/blood-200404- 1396

45. Basile DP, Yoder MC. Circulating and tissue resident endothelial progenitor cells. J Cell Physiol (2014) 229:10-6. doi:10.1002/jcp.24423

46. Medina RJ, O’Neill CL, O'Doherty TM, Wilson SE, Stitt AW. Endothelial progenitors as tools to study vascular disease. Stem Cells Int (2013) 31:1657-68. doi:10.1002/stem.1414

47. O'Neill CL, O'Doherty MT, Wilson SE, Rana AA, Hirst CE, Stitt AW, et al. Therapeutic revascularisation of ischaemic tissue: The opportunities and challenges for therapy using vascular stem/progenitor cells. Stem Cell Res Ther (2012) 3:31-7. doi: $10.1186 /$ scrt 122

48. Stitt AW, O'Neill CL, O’Doherty MT, Archer DB, Gardiner TA, Medina RJ. Vascular stem cells and ischaemic retinopathies. Prog Retin Eye Res (2011) 30:149-66. doi:10.1016/j.preteyeres.2011.02.001

49. Medina RJ, O’Neill CL, Sweeney M, Guduric-Fuchs J, Gardiner TA, Simpson DA, et al. Molecular analysis of endothelial progenitor cell (EPC) subtypes reveals two distinct cell populations with different identities. BMC Med Genomics (2010) 3:18. doi:10.1186/1755-8794-3-18

50. Medina RJ, O'Neill CL, Humphreys MW, Gardiner TA, Stitt AW. Outgrowth endothelial cells: characterization and their potential for reversing ischemic retinopathy. Invest Ophthalmol Vis Sci (2010) 51:5906-13. doi:10.1167/iovs.094951

51. Medina RJ, O’Neill CL, O’Doherty TM, Knott H, Guduric-Fuchs J, Gardiner TA, et al. Myeloid angiogenic cells act as alternative M2 macrophages and modulate angiogenesis through interleukin-8. Mol Med (2011) 17:1045-55. doi:10.2119/molmed.2011.00129

52. Heeschen C, Aicher A, Lehmann R, Fichtlscherer S, Vasa M, Urbich C, et al. Erythropoietin is a potent physiologic stimulus for endothelial progenitor cell mobilization. Blood (2003) 102:1340-6. doi:10.1182/blood-2003-01-0223

53. Asahara T, Takahashi T, Masuda H, Kalka C, Chen D, Iwaguro H, et al. VEGF contributes to postnatal neovascularization by mobilizing bone marrow-derived endothelial progenitor cells. EMBOJ (1999) 18:3964-72. doi:10.1093/emboj/18. 14.3964

54. Wolfram O, Jentsch-Ullrich K, Wagner A, Hammwoehner M, Steinke R, Franke A, et al. G-CSF-Induced mobilization of CD34 progenitor cells and 
proarrhythmic effects in patients with severe coronary artery disease. Pacing Clin Electrophysiol (2007) 30:S166-9. doi:10.1111/j.1540-8159.2007.00630.x

55. Bhatwadekar AD, Glenn JV, Curtis TM, Grant MB, Stitt AW, Gardiner TA. Retinal endothelial cell apoptosis stimulates recruitment of endothelial progenitor cells. Invest Ophthalmol Vis Sci (2009) 50:4967-73. doi:10.1167/iovs.09-3616

56. Ceradini DJ, Gurtner GC. Homing to hypoxia: HIF-1 as a mediator of progenitor cell recruitment to injured tissue. Trends Cardiovasc Med (2005) 15:57-63. doi:10.1016/j.tcm.2005.02.002

57. Ceradini DJ, Kulkarni AR, Callaghan MJ, Tepper OM, Bastidas N, Kleinman ME, et al. Progenitor cell trafficking is regulated by hypoxic gradients through HIF-1 induction of SDF-1. Nat Med (2004) 10:858-64. doi:10.1038/nm1075

58. Jie KE, Goossens MH, van Oostrom O, Lilien MR, Verhaar MC. Circulating endothelial progenitor cell levels are higher during childhood than in adult life. Atherosclerosis (2009) 202:345-7. doi:10.1016/j.atherosclerosis.2008.05.012

59. Masuda H, Kalka C, Takahashi T, Yoshida M, Wada M, Kobori M, et al. Estrogenmediated endothelial progenitor cell biology and kinetics for physiological postnatal vasculogenesis. Circ Res (2007) 101:598-606. doi:10.1161/CIRCRESAHA. 106.144006

60. Hoetzer GL, Van Guilder GP, Irmiger HM, Keith RS, Stauffer BL, DeSouza CA. Aging, exercise, and endothelial progenitor cell clonogenic and migratory capacity in men. J Appl Physiol (2007) 102:847-52. doi:10.1152/japplphysiol.01183. 2006

61. Busik JV, Tikhonenko M, Bhatwadekar A, Opreanu M, Yakubova N, Caballero $\mathrm{S}$, et al. Diabetic retinopathy is associated with bone marrow neuropathy and a depressed peripheral clock. J Exp Med (2009) 206:2897-906. doi:10.1084/jem. 20090889

62. Reinhard H, Jacobsen PK, Lajer M, Pedersen N, Billestrup N, Mandrup-Poulsen $\mathrm{T}$, et al. Multifactorial treatment increases endothelial progenitor cells in patients with type 2 diabetes. Diabetologia (2010) 53:2129-33. doi:10.1007/s00125-0101843-4

63. van Ark J, Moser J, Lexis C, Bekkema F, Pop I, van der Horst I, et al. Type 2 diabetes mellitus is associated with an imbalance in circulating endothelial and smooth muscle progenitor cell numbers. Diabetologia (2012) 55:2501-12. doi:10.1007/s00125-012-2590-5

64. Kusuyama T, Omura T, Nishiya D, Enomoto S, Matsumoto R, Takeuchi K, et al. Effects of treatment for diabetes mellitus on circulating vascular progenitor cells. J Pharmacol Sci (2006) 102:96-102. doi:10.1254/jphs.FP0060256

65. Loomans CJ, de Koning EJ, Staal FJ, Rookmaaker MB, Verseyden C, de Boer $\mathrm{HC}$, et al. Endothelial progenitor cell dysfunction a novel concept in the pathogenesis of vascular complications of type 1 diabetes. Diabetes (2004) 53:195-9. doi:10.2337/diabetes.53.1.195

66. Ingram DA, Lien IZ, Mead LE, Estes M, Prater DN, Derr-Yellin E, et al. In vitro hyperglycemia or a diabetic intrauterine environment reduces neonatal endothelial colony-forming cell numbers and function. Diabetes (2008) 57:724-31. doi:10.2337/db07-1507

67. Tan K, Lessieur E, Cutler A, Nerone P, Vasanji A, Asosingh K, et al. Impaired function of circulating $\mathrm{CD} 34^{+} \mathrm{CD} 45^{-}$cells in patients with proliferative diabetic retinopathy. Exp Eye Res (2010) 91:229-37. doi:10.1016/j.exer.2010.05.012

68. Lombardo MF, Iacopino P, Cuzzola M, Spiniello E, Garreffa C, Ferrelli F, et al. Type 2 diabetes mellitus impairs the maturation of endothelial progenitor cells and increases the number of circulating endothelial cells in peripheral blood. Cytometry A (2012) 81:856-64. doi:10.1002/cyto.a.22109

69. Fadini GP, Sartore S, Baesso I, Lenzi M, Agostini C, Tiengo A, et al. Endothelial progenitor cells and the diabetic paradox. Diabetes Care (2006) 29:714-6. doi:10.2337/diacare.29.03.06.dc05-1834

70. Tepper OM, Galiano RD, Capla JM, Kalka C, Gagne PJ, Jacobowitz GR, et al. Human endothelial progenitor cells from type II diabetics exhibit impaired proliferation, adhesion, and incorporation into vascular structures. Circulation (2002) 106:2781-6. doi:10.1161/01.CIR.0000039526.42991.93

71. Brunner S, Schernthaner G, Satler M, Elhenicky M, Hoellerl F, Schmid-Kubista $\mathrm{KE}$, et al. Correlation of different circulating endothelial progenitor cells to stages of diabetic retinopathy: first in vivo data. Invest Ophthalmol Vis Sci (2009) 50:392-8. doi:10.1167/iovs.08-1748

72. Brunner S, Hoellerl F, Schmid-Kubista KE, Zeiler F, Schernthaner G, Binder S, et al. Circulating angiopoietic cells and diabetic retinopathy in type 2 diabetes mellitus, with or without macrovascular disease. Invest Ophthalmol Vis Sci (2011) 52:4655-62. doi:10.1167/iovs.10-6520
73. Lee IG, Chae SL, Kim JC. Involvement of circulating endothelial progenitor cells and vasculogenic factors in the pathogenesis of diabetic retinopathy. Eye (2006) 20:546-52. doi:10.1038/sj.eye.6701920

74. Zerbini G, Maestroni A, Palini A, Tremolada G, Lattanzio R, Maestroni S, et al. Endothelial progenitor cells carrying monocyte markers are selectively abnormal in type 1 diabetic patients with early retinopathy. Diabetes (2012) 61:908-14. doi:10.2337/db11-1197

75. Liu X, Li Y, Liu Y, Luo Y, Wang D, Annex BH, et al. Endothelial progenitor cells (EPCs) mobilized and activated by neurotrophic factors may contribute to pathologic neovascularization in diabetic retinopathy. Am J Pathol (2010) 176:504-15. doi:10.2353/ajpath.2010.081152

76. Strijbos MH, Gratama JW, Kraan J, Lamers CH, den Bakker MA, Sleijfer S. Circulating endothelial cells in oncology: Pitfalls and promises. Br J Cancer (2008) 98:1731-5. doi:10.1038/sj.bjc.6604383

77. Werner N, Kosiol S, Schiegl T, Ahlers P, Walenta K, Link A, et al. Circulating endothelial progenitor cells and cardiovascular outcomes. N Engl J Med (2005) 353:999-1007. doi:10.1056/NEJMoa043814

78. Mendel TA, Clabough EB, Kao DS, Demidova-Rice TN, Durham JT, Zotter BC, et al. Pericytes derived from adipose-derived stem cells protect against retinal vasculopathy. PLoS One (2013) 8:e65691. doi:10.1371/journal.pone.0065691

79. Fadini GP, Mancuso P, Bertolini F, De Kreutzenberg S, Avogaro A. Amelioration of glucose control mobilizes circulating pericyte progenitor cells in type 2 diabetic patients with microangiopathy. Exp Diabetes Res (2012) 2012:1-8. doi: $10.1155 / 2012 / 274363$

80. Lee J, Lee S, Yoo S, Asahara T, Kwon S. CD34 hybrid cells promote endothelial colony-forming cell bioactivity and therapeutic potential for ischemic diseases. Arterioscler Thromb Vasc Biol (2013) 33:1622-34. doi:10.1161/ATVBAHA.112. 301052

81. Chakravarthy U, Harding SP, Rogers CA, Downes SM, Lotery AJ, Culliford LA, et al. Alternative treatments to inhibit VEGF in age-related choroidal neovascularisation: 2-year findings of the IVAN randomised controlled trial. Lancet (2013) 382:1258-67. doi:10.1016/S0140-6736(13)61501-9

82. Do DV, Nguyen QD, Boyer D, Schmidt-Erfurth U, Brown DM, Vitti R, et al. One-year outcomes of the DA VINCI study of VEGF trap-eye in eyes with diabetic macular edema. Ophthalmology (2012) 119:1658-65. doi:10.1016/j. ophtha.2012.02.010

83. Mitchell P, Bandello F, Schmidt-Erfurth U, Lang GE, Massin P, Schlingemann RO, et al. The RESTORE study: ranibizumab monotherapy or combined with laser versus laser monotherapy for diabetic macular edema. Ophthalmology (2011) 118:615-25. doi:10.1016/j.ophtha.2011.01.031

84. Elman MJ, Aiello LP, Beck RW, Bressler NM, Bressler SB, Edwards AR, et al. Randomized trial evaluating ranibizumab plus prompt or deferred laser or triamcinolone plus prompt laser for diabetic macular edema. Ophthalmology (2010) 117:e35. doi:10.1016/j.ophtha.2010.02.031

85. Jørgensen CM, Hardarson SH, Bek T. The oxygen saturation in retinal vessels from diabetic patients depends on the severity and type of vision-threatening retinopathy. Acta Ophthalmol (2014) 92:34-9. doi:10.1111/aos.12283

86. Hardarson SH. Retinal oximetry. Acta Ophthalmol (2013) 91:1-47. doi:10.1111/ aos. 12086

Conflict of Interest Statement: The authors declare that the research was conducted in the absence of any commercial or financial relationships that could be construed as a potential conflict of interest.

Received: 28 February 2014; accepted: 21 March 2014; published online: 09 April 2014. Citation: Lois N, McCarter RV, O'Neill C, Medina RJ and Stitt AW (2014) Endothelial progenitor cells in diabetic retinopathy. Front. Endocrinol. 5:44. doi: 10.3389/fendo.2014.00044

This article was submitted to Diabetes, a section of the journal Frontiers in Endocrinology.

Copyright (C) 2014 Lois, McCarter, O'Neill, Medina and Stitt. This is an open-access article distributed under the terms of the Creative Commons Attribution License (CC $B Y)$. The use, distribution or reproduction in other forums is permitted, provided the original author(s) or licensor are credited and that the original publication in this journal is cited, in accordance with accepted academic practice. No use, distribution or reproduction is permitted which does not comply with these terms. 